\title{
COURSE AND PROGNOSIS IN RHEUMATOID ARTHRITIS
}

\section{A FURTHER REPORT}

\author{
BY \\ J. J. R. DUTHIE, P. E. BROWN, L. H. TRUELOVE*, F. D. BARAGAR*, AND A. J. LAWRIE \\ From the Rheumatic Diseases Unit, Northern General Hospital, Edinburgh
}

Twopreviouscommunications(Duthie, Thompson, Weir, and Fletcher, 1955; Duthie, Brown, Knox, and Thompson, 1957) have reported successive stages in a study of the results of treatment in hospital and the subsequent course of a large group of patients with rheumatoid arthritis. This study was undertaken in order to determine:

(1) The immediate results of hospital treatment, as measured by changes in functional capacity and disease activity;

(2) The length of time improvement could be maintained with adequate after-care;

(3) The factors which might have a bearing on prognosis;

(4) The influence of the disease on the patient's social and economic status.

The original group consisted of 307 patients admitted to the Rheumatic Unit in the Northern General Hospital, Edinburgh, between June, 1948, and July, 1951, admission to hospital having been decided upon because of active disease, the presence of deformities, or both. While in hospital all the patients were put under the same basic regimen, comprising rest in bed, the application of plaster splints to affected joints, aspirin to the limits of tolerance, physiotherapy, and a graduated return to the highest attainable functional level. Drugs other than aspirin were avoided. After discharge the patients were seen at regular intervals and their treatment modified as the need arose. Splints were renewed and help was provided with domestic and employment problems. At this stage drugs were given whenever they were indicated.

The group has now been followed for approximately 9 years since discharge and the present report deals with the most recent developments, particularly those relating to the long-term course and prognosis. Its conclusions are naturally based on cases which

* Present address: Rheumatic Unit, Manitoba Rehabilitation Hospital, Winnipeg, Manitoba, Canada. were severe enough to be selected for hospital treatment and do not necessarily apply to the milder cases with little or no disability which may never be referred to hospital and which have been shown to make up a considerable proportion of the total number of people with rheumatoid arthritis in the whole population (Kellgren, Lawrence, and AitkenSwan, 1953).

The composition of the group is given in Table $I$. Of the original 307 patients, 200 were examined at the final assessment. Of the remainder, 75 had died, and 32 had left the district or had withdrawn for various reasons or were untraceable.

TABLE I

COMPOSITION OF THE GROUP, BY SEX

\begin{tabular}{|c|c|c|c|}
\hline \multirow{2}{*}{ Data } & \multicolumn{3}{|c|}{ Sex } \\
\hline & Male & Female & Total \\
\hline \multirow{2}{*}{$\begin{array}{l}\text { Number of cases admitted between } \\
\text { June, } 1948 \text {, and July, } 1951 \ldots \\
\text { Mean duration of stay in hospital (wks) }\end{array}$} & 88 & 219 & 307 \\
\hline & \multicolumn{3}{|c|}{$9 \cdot 4$} \\
\hline $\begin{array}{c}\text { Period between Discharge and First } \\
\text { Assessment (mths) } \quad \ldots \quad \ldots\end{array}$ & \multicolumn{3}{|c|}{ (range 12 to 50 ) } \\
\hline 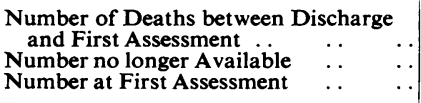 & $\begin{array}{r}6 \\
5 \\
77\end{array}$ & $\begin{array}{r}9 \\
5 \\
205\end{array}$ & $\begin{array}{r}15 \\
10 \\
282\end{array}$ \\
\hline $\begin{array}{c}\text { Period between Discharge and Fourth } \\
\text { Assessment (mths) } \ldots\end{array}$ & \multicolumn{3}{|c|}{$\begin{array}{l}107 \cdot 5 \\
\text { (range } 93 \text { to } 132 \text { ) }\end{array}$} \\
\hline $\begin{array}{l}\text { Number of Deaths between Discharge } \\
\begin{array}{l}\text { and Fourth Assessment } \\
\text { Number no longer Available }\end{array} \\
\text { Number at Fourth Assessment } \\
\text { Numb }\end{array}$ & $\begin{array}{r}28 \\
9 \\
51\end{array}$ & $\begin{array}{r}47 \\
23 \\
149\end{array}$ & $\begin{array}{r}75 \\
32 \\
200\end{array}$ \\
\hline
\end{tabular}

Deaths.-The causes of death are classified in Table II (overleaf), where the percentages of the major causes are compared with those given by Cobb, Anderson, and Bauer (1953). The proportion of deaths due to heart disease is considerably higher than that found by the American authors, 36 per cent. as against 19 per cent. The proportion attributable to infection is correspondingly lower, 14 per cent. as against 41 per cent. The higher average age of the Edinburgh series and the availability of antibiotics no doubt account for part of these differences. 
TABLE II

CAUSES OF DEATH

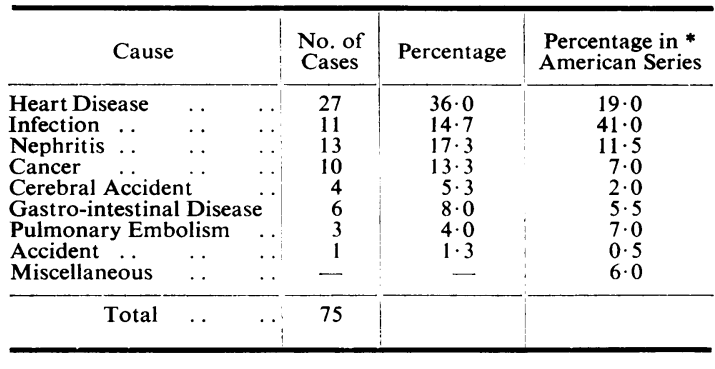

* Cobb, Anderson, and Bauer (1953).

The death rates in the Edinburgh series are higher than those of the general population at all ages in both sexes (Table III). It will be seen that Cobb and his colleagues, whose series contained a relatively high proportion of younger patients, found an excess mortality only in those under 50 years of age.

Methods of Assessment.-The methods used in assessing functional capacity and disease activity were described in the earlier reports. For convenience they are summarized in Tables IV and V.

\section{Results}

Changes in Functional Capacity.-The functional capacity on admission to hospital, at discharge, and at the four follow-up assessments is shown in Table VI and Fig. 1 (opposite). The follow-up assessments were carried out at approximately $2,4,6$, and 9 years after discharge. Fig. 1 emphasizes the
TABLE IV

GRADES OF FUNCTIONAL CAPACITY

\begin{tabular}{c|c|c}
\hline Grade & Definition & \multicolumn{1}{|c}{ Remarks } \\
\hline I & $\begin{array}{c}\text { Fit for all normal } \\
\text { activities }\end{array}$ & $\begin{array}{l}\text { Full employment in usual } \\
\text { work } \\
\text { Full house duties }\end{array}$ \\
\hline II & Moderate restriction & $\begin{array}{l}\text { Usual employment with } \\
\text { modifications } \\
\text { Light or part-time work } \\
\text { All housework save the } \\
\text { heaviest } \\
\text { No dependency on others }\end{array}$ \\
\hline III & Marked restriction & $\begin{array}{l}\text { Only very light work or } \\
\text { light housework depend- } \\
\text { Some degree of depend } \\
\text { ency on others }\end{array}$ \\
\hline IV & Confined to chair or bed & $\begin{array}{l}\text { Not capable of any work } \\
\text { Completely dependent on } \\
\text { others }\end{array}$ \\
\hline
\end{tabular}

marked improvement which occurred between admission and discharge. After discharge the changes in functional capacity were less consistent. Between discharge and the first assessment the proportion of cases in Grade I increased at the expense of those in Grade II and in the same period a slight increase took place in Grades III and IV. The overall position, however, was one of improvement.

From the first assessment onwards there has been a gradual and progressive deterioration in the group as a whole. Some deterioration, of course, was to be expected because of ageing and degenerative changes in the joints. Nevertheless, over 20 per

TABLE III

DEATH RATES PER 1,000 PATIENT YEARS OF OBSERVATION BY SEX AND AGE IN SCOTLAND AND AMERICA COMPARED

Expected values for Scotland are based on Scottish Life Tables, 1950-52. American figures are from Cobb, Anderson, and Bauer (1953)

\begin{tabular}{|c|c|c|c|c|c|c|c|}
\hline \multirow{2}{*}{ Series } & \multirow{2}{*}{ Life Table Age } & \multicolumn{3}{|c|}{ Men } & \multicolumn{3}{|c|}{ Women } \\
\hline & & Deaths & $\begin{array}{c}\text { Observed } \\
\text { Rate }\end{array}$ & $\begin{array}{c}\text { Expected } \\
\text { Rate }\end{array}$ & Deaths & $\begin{array}{c}\text { Observed } \\
\text { Rate }\end{array}$ & $\begin{array}{c}\text { Expected } \\
\text { Rate }\end{array}$ \\
\hline Scotland & $\begin{array}{l}\text { Under } 50 \\
50-59 \\
\text { Over } 60\end{array}$ & $\begin{array}{r}1 \\
8 \\
20\end{array}$ & $\begin{array}{r}4 \cdot 8 \\
37 \cdot 8 \\
84 \cdot 4\end{array}$ & $\begin{array}{r}4 \cdot 6 \\
16 \cdot 8 \\
54 \cdot 3\end{array}$ & $\begin{array}{r}7 \\
11 \\
28\end{array}$ & $\begin{array}{l}11.9 \\
19.9 \\
44.7\end{array}$ & $\begin{array}{r}3 \cdot 6 \\
10 \cdot 2 \\
36 \cdot 5\end{array}$ \\
\hline America & $\begin{array}{l}\text { Under } 50 \\
\text { Over } 50 \\
\text { All Ages }\end{array}$ & $\begin{array}{l}33 \\
25 \\
58\end{array}$ & $\begin{array}{l}20 \cdot 6 \\
38 \cdot 4 \\
25 \cdot 7\end{array}$ & $\begin{array}{r}3 \cdot 9 \\
47 \cdot 1 \\
16 \cdot 4\end{array}$ & $\begin{array}{l}20 \\
59 \\
79\end{array}$ & $\begin{array}{l}10 \cdot 7 \\
39 \cdot 7 \\
23 \cdot 8\end{array}$ & $\begin{array}{r}2 \cdot 9 \\
41 \cdot 6 \\
20 \cdot 0\end{array}$ \\
\hline
\end{tabular}

TABLE $\mathrm{V}$

GRADES OF DISEASE ACTIVITY

\begin{tabular}{|c|c|c|c|c|c|}
\hline Grade & Degree of Activity & $\begin{array}{l}\text { Erythrocyte Sedimentation } \\
\text { Rate }(\mathrm{mm} . / \mathrm{hr})\end{array}$ & $\begin{array}{l}\text { Haemoglobin } \\
\text { (per cent.) }\end{array}$ & Joint Involvement & Systemic Disturbance \\
\hline 1 & Inactive & 20 or Under & 85 or Over & No symptoms due to joint & None \\
\hline 2 & Moderately Active & $20-60$ & $65-85$ & $\begin{array}{l}\text { Signs of disease activity in } \\
\text { several joints }\end{array}$ & Moderate, weight steady \\
\hline 3 & Very Active & Over 60 & 65 or Under & $\begin{array}{l}\text { Signs of acute inflammation } \\
\text { in many joints }\end{array}$ & Marked, with loss of weight \\
\hline
\end{tabular}


TABLE VI

FUNCTIONAL CAPACITY ON ADMISSION, DISCHARGE, AND FIRST, SECOND, THIRD, AND FOURTH ASSESSMENTS

\begin{tabular}{|c|c|c|c|c|c|c|c|c|c|c|}
\hline \multirow{2}{*}{\multicolumn{4}{|c|}{ Time of Estimation }} & \multirow{2}{*}{$\begin{array}{l}\text { No. of } \\
\text { Cases }\end{array}$} & \multicolumn{6}{|c|}{ Functional Grades (per cent. of total) } \\
\hline & & & & & I & II & III & IV & $\mathbf{I}+\mathbf{I I}$ & $I I I+I V$ \\
\hline $\begin{array}{l}\text { Admission } \\
\text { Discharge } \\
\text { First Assessment . . } \\
\text { Second Assessment } \\
\text { Third Assessment } \\
\text { Fourth Assessment }\end{array}$ & $\begin{array}{l}\cdots \\
\cdots \\
\cdots \\
\cdots \\
\cdots\end{array}$ & $\begin{array}{l}\cdots \\
\cdots \\
\cdots \\
\cdots \\
\cdots\end{array}$ & $\begin{array}{l}\cdots \\
\cdots \\
\cdots \\
\cdots \\
\cdots\end{array}$ & $\begin{array}{l}282 \\
282 \\
282 \\
258 \\
247 \\
200\end{array}$ & $\begin{array}{l}\overline{11 \cdot 3} \\
28 \cdot 4 \\
27 \cdot 9 \\
23 \cdot 5 \\
20 \cdot 5\end{array}$ & $\begin{array}{l}35 \cdot 4 \\
64 \cdot 2 \\
44 \cdot 0 \\
42 \cdot 2 \\
40 \cdot 5 \\
41 \cdot 0\end{array}$ & $\begin{array}{l}42 \cdot 6 \\
24 \cdot 1 \\
25 \cdot 1 \\
23 \cdot 6 \\
26 \cdot 7 \\
27 \cdot 0\end{array}$ & $\begin{array}{r}22 \cdot 0 \\
0 \cdot 4 \\
2 \cdot 5 \\
6 \cdot 2 \\
9 \cdot 3 \\
11 \cdot 5\end{array}$ & $\begin{array}{l}35 \cdot 4 \\
75 \cdot 5 \\
72 \cdot 4 \\
70 \cdot 1 \\
64 \cdot 0 \\
61 \cdot 5\end{array}$ & $\begin{array}{l}64 \cdot 6 \\
24 \cdot 5 \\
27 \cdot 6 \\
29 \cdot 9 \\
36 \cdot 0 \\
38 \cdot 5\end{array}$ \\
\hline
\end{tabular}

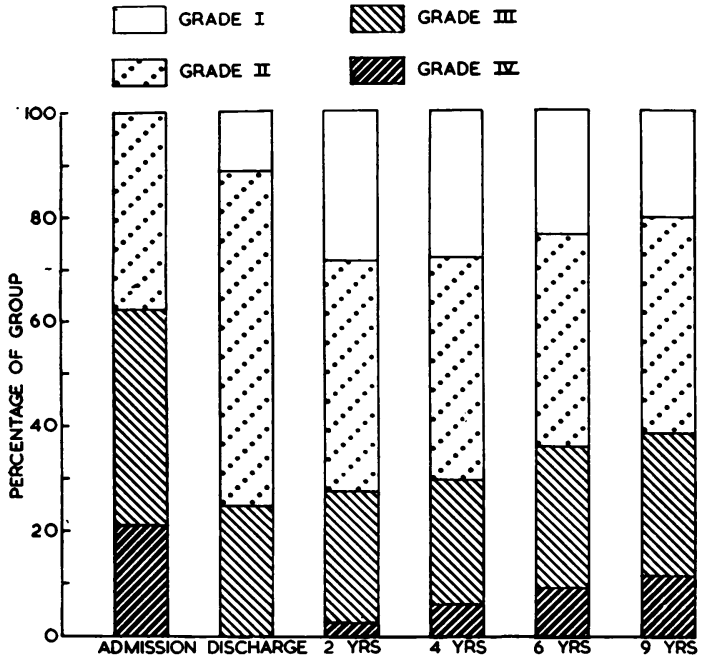

Fig. 1.-Grades of functional capacity on admission and discharge, and at later assessments.

cent. were still in Grade I at the fourth assessment and less than 12 per cent. had become entirely dependent on others. Rather more than 60 per cent. retained a useful level of functional capacity.

Changes in Disease Activity.-The disease activity on admission, at discharge, and at the four follow-up assessments is given in Table VII and Fig. 2. The pattern differs from that of the functional capacity and shows no well-defined characteristics. On admission just over 25 per cent. were classed as very active and 10 per cent. as inactive. The number of very active cases fell to 5 per cent. on discharge, and 35 per cent. had become inactive. Since then the very active cases, apart from a transient rise to 12 per cent. at the second assessment, have remained at just under 5 per cent. and the inactive cases have fluctuated between 20 and 30 per cent.

Capacity for Work.-Although functional capacity and disease activity are useful guides to the results
TABLE VII

DISEASE ACTIVITY ON ADMISSION, DISCHARGE, AND FIRST, SECOND, THIRD, AND FOURTH ASSESSMENTS

\begin{tabular}{|c|c|c|c|c|c|}
\hline \multirow{2}{*}{$\begin{array}{c}\text { Time of } \\
\text { Estimation }\end{array}$} & & \multirow{2}{*}{$\begin{array}{l}\text { No. of } \\
\text { Cases }\end{array}$} & \multicolumn{3}{|c|}{ Disease Activity (per cent.) } \\
\hline & & & $\begin{array}{c}\text { Very } \\
\text { Active }\end{array}$ & $\begin{array}{c}\text { Moderately } \\
\text { Active }\end{array}$ & Inactive \\
\hline $\begin{array}{l}\text { Admission } \\
\text { Discharge.. } \\
\text { First Assessment } \\
\text { Second Assessment } \\
\text { Third Assessment } \\
\text { Fourth Assessment }\end{array}$ & \begin{tabular}{l|}
$\cdots$ \\
$\cdots$ \\
$\cdots$ \\
$\cdots$ \\
$\cdots$
\end{tabular} & $\begin{array}{l}282 \\
282 \\
282 \\
258 \\
247 \\
200\end{array}$ & $\begin{array}{r}26 \cdot 2 \\
5 \cdot 0 \\
3 \cdot 5 \\
12 \cdot 0 \\
1 \cdot 2 \\
2 \cdot 5\end{array}$ & $\begin{array}{l}63 \cdot 5 \\
59 \cdot 2 \\
65 \cdot 6 \\
61 \cdot 2 \\
69 \cdot 6 \\
73 \cdot 5\end{array}$ & $\begin{array}{l}10 \cdot 3 \\
35 \cdot 8 \\
30 \cdot 9 \\
26 \cdot 8 \\
29 \cdot 2 \\
24 \cdot 0\end{array}$ \\
\hline
\end{tabular}

$\square$ inactive $\because$ moderately active ZIIIA Very active

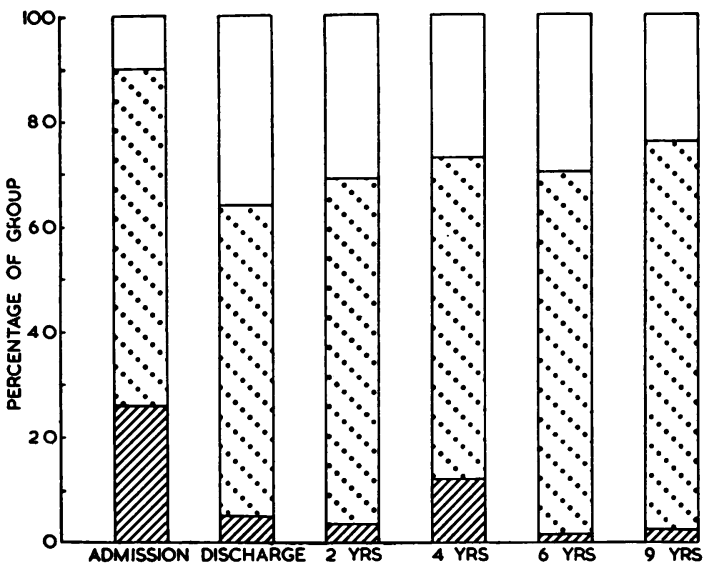

Fig. 2.-Disease activity on admission and discharge, and at later assessments.

of treatment, it is important also to consider the patient's ability to resume his ordinary duties after discharge from hospital. Only 76 of the original 307 had been gainfully employed in the year before admission. At the actual time of admission only four of these were in normal employment and fourteen in light work. The rest were not working. 
Two years after discharge, 29 were in normal employment and 33 in light work. At the final assessment 46 of these patients were still available, of whom 22 were in normal employment and fifteen in light work.

Of the 171 housewives in the original group none was fit for all household duties at the time of admission. Fifteen were fit for all duties except the heaviest, 87 were fit for light housework, and 69 were unfit for any kind of work. 2 years after discharge, 27 were fit for all duties, 78 for all but the heaviest, and 47 for light housework, and nineteen were still totally incapacitated. 125 housewives remained at the final assessment. Of these, 23 were fit for all duties and $\mathbf{5 7}$ for all duties but the heaviest.

The results show that, out of the working population of 46 men and 125 women who remained at the fourth assessment, just over 68 per cent. were still usefully employed.

\section{Prognosis}

A knowledge of the usual course of a disease, obtained by the study of a large group of patients, is essential in prognosis. But this is only the first step. For individual cases it is necessary to modify the group prognosis by taking into account the particular factors which influence the severity of the disease.

Short and Bauer (1948) considered the prognosis in rheumatoid arthritis more favourable in men than in women, and also in patients whose illness started before the age of 40 and in those with asymmetrical joint involvement at onset. Those whose weight was below the average on admission to hospital did badly. Bywaters and Dresner (1952) agreed that men did better than women and that an early onset was also favourable. Other favourable circumstances were: a short duration of illness, a low erythrocyte sedimentation rate (E.S.R.), absence of anaemia, and absence of radiological changes in the joints.

In the present series, consideration has previously been given to: the duration of disease on admission, the age at onset, the distribution of affected joints, the economic class, type of work, sex, type of course, disease activity on admission and discharge, haemoglobin levels and E.S.R. on admission, and the results of sensitized sheep cell tests.

At the assessment made 2 years after discharge the patients were grouped according to the symmetry or asymmetry of their joint involvement on admission. No significant difference was then found in the functional capacity of the two groups at admission or at follow-up and it was concluded that the pattern of joint involvement at the time of admission was of no value in predicting the response to treatment. At the first assessment, also, it appeared that the professional and clerical classes had fared less well than the manual workers, but by the third assessment this difference had disappeared. When manual workers were classified according to the amount of physical effort required in their work, it was found that this factor had no effect on subsequent functional capacity and that those performing heavy tasks were no worse off than the others.

Because of these findings, the distribution of affected joints, economic class, and type of work have not been further considered in relation to prognosis in the present report. Instead, the significance of rheumatic nodules and the possible effects of treatment during the follow-up period have been included.

Duration of Disease. - The duration of the disease at the time of admission to hospital was one of the factors expected to influence the response to treatment. At the first assessment it was found that the percentage of cases in functional Grade I was highest in patients admitted within 1 year of onset ( 43 per cent.) and lowest in those admitted more than 5 years after onset (16 per cent.). Corresponding differences were found in the proportion in Grades I and II. This advantage in favour of those admitted soon after onset has been maintained throughout the investigation. Details are given in Table VIII (opposite).

A less distinctive pattern was found in respect of disease activity (Table IX, opposite).

Age at Onset.-When patients were grouped according to the age at onset very little difference was seen in the proportions in Grades I and II at the first assessment. The patients with the later onset, however, had shown greater response in terms of improvement by one or more grades than had those with an onset in early or middle life.

By the third assessment this pattern had begun to change. The group with a late onset had only 46 per cent. in Grades I and II compared with 63 and 70 per cent. of those with onset in middle and early life. At the fourth assessment those with onset in middle life had fallen behind those with onset in early life, while the older group appeared to have improved as a result of the loss by death of some of its more disabled members (Table X, opposite).

Clearly, these changes reflect the general effects of ageing rather than any characteristic of the disease itself. 
TABLE VIII

RELATIONSHIP BETWEEN FUNCTIONAL CAPACITY AND DURATION OF DISEASE ON ADMISSION

\begin{tabular}{|c|c|c|c|c|c|c|c|c|c|c|c|c|}
\hline $\begin{array}{l}\text { Duration of Disease at } \\
\text { Time of Admission (yrs) }\end{array}$ & \multicolumn{3}{|c|}{ Under 1} & \multicolumn{3}{|c|}{$1-5$} & \multicolumn{3}{|c|}{$5-10$} & \multicolumn{3}{|c|}{ Over 10} \\
\hline \multirow{3}{*}{ Time of Estimation } & \multirow{3}{*}{$\begin{array}{l}\text { No. of } \\
\text { Cases }\end{array}$} & \multirow{2}{*}{\multicolumn{2}{|c|}{$\frac{\text { Per cent. }}{\text { Grade }}$}} & \multirow{3}{*}{$\begin{array}{l}\text { No. of } \\
\text { Cases }\end{array}$} & \multirow{2}{*}{\multicolumn{2}{|c|}{$\frac{\text { Per cent. }}{\text { Grade }}$}} & \multirow{3}{*}{$\begin{array}{l}\text { No. of } \\
\text { Cases }\end{array}$} & \multirow{2}{*}{\multicolumn{2}{|c|}{$\frac{\text { Per cent. }}{\text { Grade }}$}} & \multirow{3}{*}{$\begin{array}{l}\text { No. of } \\
\text { Cases }\end{array}$} & \multirow{2}{*}{\multicolumn{2}{|c|}{$\begin{array}{c}\text { Per cent. } \\
\text { Grade }\end{array}$}} \\
\hline & & & & & & & & & & & & \\
\hline & & I & $I+I I$ & & I & I + II & & I & $I+I I$ & & I & $I+I I$ \\
\hline $\begin{array}{l}\text { Admission } \\
\text { Discharge }\end{array}$ & $\begin{array}{l}84 \\
84 \\
84 \\
78 \\
75 \\
64\end{array}$ & $\begin{array}{l}\overrightarrow{14 \cdot 3} \\
42 \cdot 9 \\
47 \cdot 4 \\
42 \cdot 7 \\
37 \cdot 5\end{array}$ & $\begin{array}{l}32 \cdot 1 \\
85 \cdot 7 \\
83 \cdot 3 \\
85 \cdot 9 \\
76 \cdot 0 \\
73 \cdot 4\end{array}$ & $\begin{array}{l}81 \\
81 \\
81 \\
75 \\
73 \\
62\end{array}$ & $\begin{array}{l}\overline{12 \cdot 3} \\
30 \cdot 9 \\
28 \cdot 0 \\
23 \cdot 3 \\
16 \cdot 1\end{array}$ & $\begin{array}{l}37 \cdot 0 \\
83 \cdot 9 \\
75 \cdot 3 \\
72 \cdot 0 \\
68 \cdot 5 \\
56 \cdot 5\end{array}$ & $\begin{array}{l}49 \\
49 \\
49 \\
43 \\
41 \\
32\end{array}$ & $\begin{array}{r}\overline{6 \cdot 1} \\
16 \cdot 3 \\
11 \cdot 6 \\
9 \cdot 8 \\
9 \cdot 4\end{array}$ & $\begin{array}{l}34 \cdot 7 \\
59 \cdot 2 \\
63 \cdot 5 \\
62 \cdot 8 \\
63 \cdot 4 \\
59 \cdot 4\end{array}$ & $\begin{array}{l}68 \\
68 \\
68 \\
62 \\
58 \\
42\end{array}$ & $\begin{array}{r}\overline{10 \cdot 3} \\
16 \cdot 2 \\
14 \cdot 5 \\
8 \cdot 6 \\
9 \cdot 5\end{array}$ & $\begin{array}{l}38 \cdot 2 \\
64 \cdot 7 \\
60 \cdot 3 \\
53 \cdot 2 \\
43 \cdot 1 \\
52 \cdot 4\end{array}$ \\
\hline
\end{tabular}

TABLE IX

RELATIONSHIP BETWEEN DISEASE ACTIVITY AT ALL ASSESSMENTS AND DURATION OF DISEASE ON ADMISSION

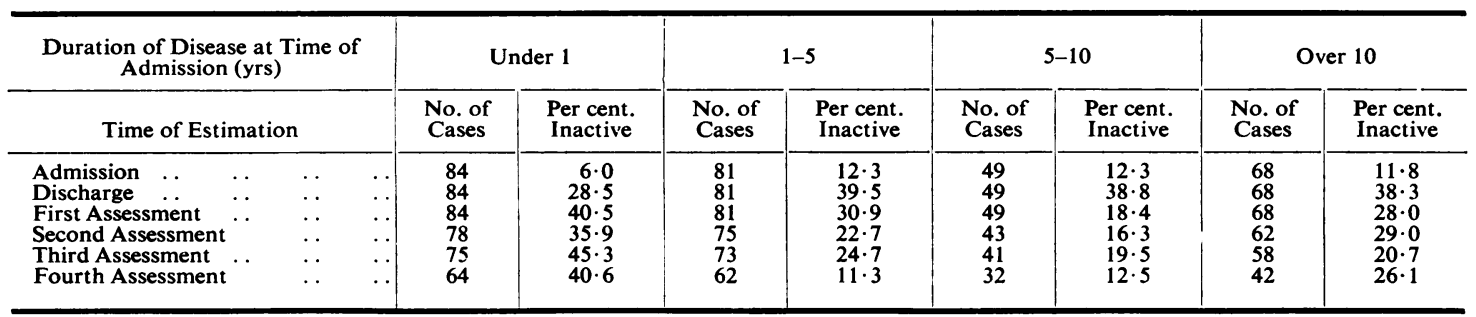

TABLE $\mathbf{X}$

RELATIONSHIP BETWEEN FUNCTIONAL CAPACITY AND AGE AT ONSET

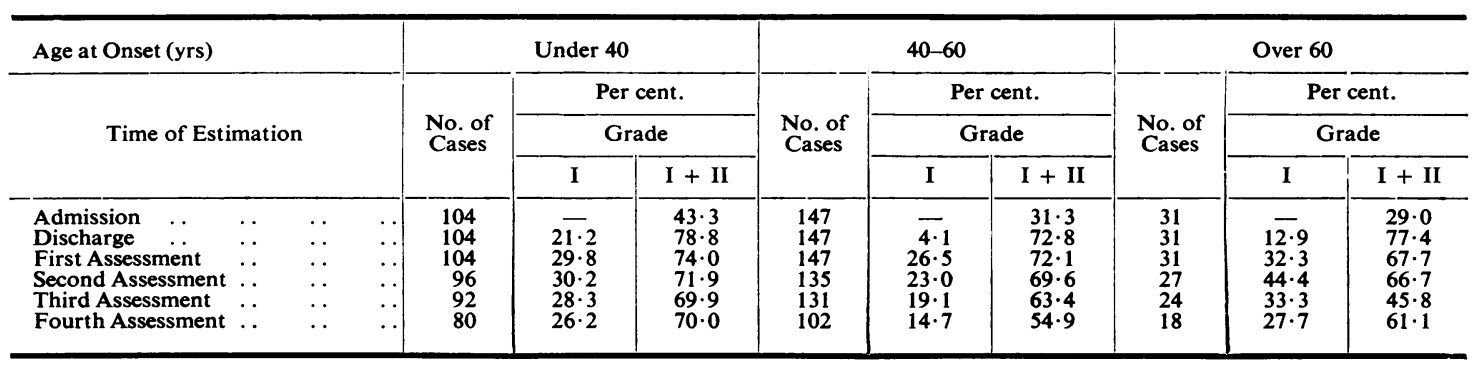

Sex.-Between admission and discharge the men showed a considerably greater improvement in functional capacity than the women. They maintained their advantage until the third assessment when the percentage of men in Grades I and II was 75 , while that of women was 60 . At the fourth assessment the difference had been greatly reduced (Table XI, overleaf) and there was a particularly striking decline in the number of men in Grade I.

Type of Course.- In previous reports it was noted that patients with an acute onset and a rapidly progressive course up to the time of admission tended to do relatively well after discharge. This tendency was maintained at the fourth assessment, when 53 per cent, of these patients were still in functional Grade I compared with 14 per cent. of those in whom the disease ran a more insidious course. As all the rapidly progressive cases were admitted within 1 year of onset, the 53 per cent. in Grade I ought, perhaps, to be compared with the 20 per cent. of insidious cases admitted within the same period. 
TABLE XI

FUNCTIONAL CAPACITY IN MEN AND WOMEN

\begin{tabular}{|c|c|c|c|c|c|c|c|c|c|}
\hline \multirow{4}{*}{\multicolumn{2}{|c|}{ Time of Estimation }} & \multicolumn{4}{|c|}{ Men } & \multicolumn{4}{|c|}{ Women } \\
\hline & & \multirow{3}{*}{$\begin{array}{l}\text { No. of } \\
\text { Cases }\end{array}$} & \multicolumn{3}{|c|}{ Per cent. } & \multirow{3}{*}{$\begin{array}{l}\text { No. of } \\
\text { Cases }\end{array}$} & \multicolumn{3}{|c|}{ Per cent. } \\
\hline & & & \multicolumn{3}{|c|}{ Grade } & & \multicolumn{3}{|c|}{ Grade } \\
\hline & & & I & $I+I I$ & III + IV & & 1 & $\mathbf{I}+\mathbf{I I}$ & $I I I+I V$ \\
\hline $\begin{array}{l}\text { Admission } \\
\text { Discharge }\end{array}$. & $\begin{array}{l}\cdots \\
\cdots \\
\cdots \\
\cdots \\
\cdots\end{array}$ & $\begin{array}{l}77 \\
77 \\
77 \\
69 \\
65 \\
51\end{array}$ & $\begin{array}{r}\overline{7 \cdot 8} \\
41 \cdot 5 \\
40 \cdot 6 \\
38 \cdot 5 \\
27 \cdot 5\end{array}$ & $\begin{array}{l}36 \cdot 4 \\
83 \cdot 1 \\
84 \cdot 4 \\
81 \cdot 2 \\
75 \cdot 4 \\
66 \cdot 7\end{array}$ & $\begin{array}{l}63 \cdot 6 \\
16 \cdot 9 \\
15 \cdot 6 \\
18 \cdot 8 \\
24 \cdot 6 \\
33 \cdot 3\end{array}$ & $\begin{array}{l}205 \\
205 \\
205 \\
189 \\
182 \\
149\end{array}$ & $\begin{array}{l}\overline{12 \cdot 7} \\
23 \cdot 4 \\
23 \cdot 3 \\
18 \cdot 1 \\
18 \cdot 1\end{array}$ & $\begin{array}{l}35 \cdot 1 \\
72 \cdot 7 \\
67 \cdot 8 \\
66 \cdot 1 \\
59 \cdot 9 \\
59 \cdot 7\end{array}$ & $\begin{array}{l}64 \cdot 9 \\
27 \cdot 3 \\
32 \cdot 2 \\
33 \cdot 9 \\
40 \cdot 1 \\
40 \cdot 3\end{array}$ \\
\hline
\end{tabular}

\section{Functional Capacity}

On Discharge.-The relationship between funcassessments is shown in Table XII and Fig. 3.

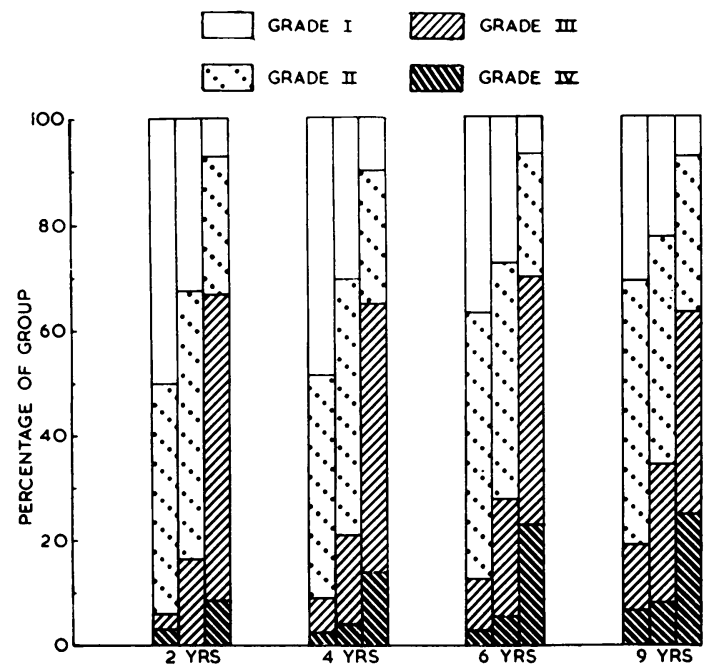

Fig. 3.-Grades of functional capacity at the four follow-up assessments, related to functional capacity on discharge. Left-hand section of each column refers to cases discharged in Grade I, middle section to cases discharged in Grade II, and right-hand section to cases discharged in Grade III. tional capacity on discharge and at subsequent

Of those discharged in Grade I, 81 per cent. were in Grades I or II at the fourth assessment, compared with 65 per cent. of those discharged in Grade II. The functional capacity on discharge, therefore, appears to give a reliable guide to future progress, but it must be remembered that a substantial proportion of patients discharged in Grade II continued to improve up till the first 2-year assessment.

At Later Assessments. - After the first assessment the functional capacity remained relatively stable. Movements between the grades followed a more or less orderly pattern which has been studied in detail elsewhere (Brown and Duthie, 1958). This pattern can, in fact, be represented in the form of a matrix such as that shown in Table XIII, which has been obtained by combining the inter-grade movements between the first and second, second and third, and third and fourth assessments.

TABLE XIII

\begin{tabular}{c|c|c|c|c|c}
\hline \multirow{2}{*}{$\begin{array}{c}\text { Grade at } \\
\text { Given Assessment }\end{array}$} & \multicolumn{3}{|c}{$\begin{array}{c}\text { Probable Percentage Distribution of } \\
\text { Grades at Next 2-year Assessment }\end{array}$} \\
\cline { 2 - 6 } & \multicolumn{1}{|c|}{ I } & II & III & IV & Dead \\
\hline II & $68 \cdot 8$ & $28 \cdot 7$ & $1 \cdot 0$ & - & $1 \cdot 5$ \\
II & $8 \cdot 1$ & $64 \cdot 8$ & $19 \cdot 9$ & $1 \cdot 3$ & $5 \cdot 9$ \\
III & $1 \cdot 1$ & $9 \cdot 4$ & $55 \cdot 8$ & $18 \cdot 2$ & $15 \cdot 5$ \\
IV & - & $2 \cdot 2$ & $17 \cdot 8$ & $55 \cdot 6$ & $24 \cdot 4$ \\
\hline
\end{tabular}

TABLE XII

RELATIONSHIP BETWEEN FUNCTIONAL CAPACITY ON DISCHARGE AND LATER

\begin{tabular}{|c|c|c|c|c|c|c|c|c|c|c|}
\hline \multicolumn{2}{|c|}{ Functional Capacity on Discharge } & \multicolumn{3}{|c|}{ Grade I } & \multicolumn{3}{|c|}{ Grade II } & \multicolumn{3}{|c|}{ Grades III and IV } \\
\hline \multirow{3}{*}{\multicolumn{2}{|c|}{ Time of Estimation }} & \multirow{3}{*}{$\begin{array}{l}\text { No. of } \\
\text { Cases }\end{array}$} & \multirow{2}{*}{\multicolumn{2}{|c|}{$\frac{\text { Per cent. }}{\text { Grade }}$}} & \multirow{3}{*}{$\begin{array}{l}\text { No. of } \\
\text { Cases }\end{array}$} & \multirow{2}{*}{\multicolumn{2}{|c|}{$\begin{array}{c}\text { Per cent. } \\
\text { Grade }\end{array}$}} & \multirow{3}{*}{$\begin{array}{l}\text { No. of } \\
\text { Cases }\end{array}$} & \multirow{2}{*}{\multicolumn{2}{|c|}{$\frac{\text { Per cent. }}{\text { Grade }}$}} \\
\hline & & & & & & & & & & \\
\hline & & & I & $I+I I$ & & I & $I+I I$ & & I & $I+I I$ \\
\hline $\begin{array}{l}\text { First Assessment. . } \\
\text { Second Assessment } \\
\text { Third Assessment } \\
\text { Fourth Assessment }\end{array}$ & $\begin{array}{l}\ldots \\
\cdots \\
\cdots\end{array}$ & $\begin{array}{l}32 \\
31 \\
30 \\
26\end{array}$ & $\begin{array}{l}50 \cdot 0 \\
48 \cdot 4 \\
36 \cdot 7 \\
30 \cdot 8\end{array}$ & $\begin{array}{l}93 \cdot 8 \\
90 \cdot 3 \\
86 \cdot 7 \\
80 \cdot 8\end{array}$ & $\begin{array}{l}181 \\
167 \\
160 \\
133\end{array}$ & $\begin{array}{l}32 \cdot 6 \\
30 \cdot 5 \\
27 \cdot 5 \\
22 \cdot 6\end{array}$ & $\begin{array}{l}83 \cdot 4 \\
79 \cdot 0 \\
71 \cdot 9 \\
65 \cdot 4\end{array}$ & $\begin{array}{l}69 \\
60 \\
57 \\
41\end{array}$ & $\begin{array}{r}7 \cdot 2 \\
10 \cdot 0 \\
7 \cdot 0 \\
7 \cdot 3\end{array}$ & $\begin{array}{l}33 \cdot 3 \\
35 \cdot 0 \\
29 \cdot 8 \\
36 \cdot 6\end{array}$ \\
\hline
\end{tabular}


This matrix can be used to predict the state of affairs at any subsequent assessment. Starting with the first assessment the predicted distribution of grades at the fourth assessment is:

Grade I, 21.3 per cent.

Grade II, $39 \cdot 4$ per cent.

Grade III, $27 \cdot 3$ per cent.

Grade IV, $12 \cdot 0$ per cent.

The observed percentages were: $20 \cdot 5,41 \cdot 0,27 \cdot 0$, and 11.5 respectively. Predictions carried beyond the fourth assessment suggest that the percentage of cases in Grades I and II is unlikely to fall below 57 for some years to come.

A second feature of this matrix is that it demonstrates that sub-groups containing a high proportion of Grade I cases are likely to show a greater rate of deterioration than other sub-groups. This explains, in part, the disappearance of differences between men and women and between manual and nonmanual workers.

A third feature of the matrix is the higher mortality shown in the lower functional grades. Nearly a quarter of those in Grade IV failed to survive till the next assessment. The effect of this differential mortality is to give a rather more favourable picture of the outcome of the disease than the actual facts warrant.

Age and Functional Capacity.-Although the number of cases remaining in the survey is not sufficient to provide statistically significant results, it was felt that some attempt should be made to ascertain the effect of age on functional capacity. The inter-grade movements between the third and fourth assessments have been broken down according to age and are given in Table XIV. This Table supports the impression that age has an important influence in determining which patients remain in Grade I and which lapse into Grade IV.

Disease Activity. - The majority of patients (93 per cent.) showed signs of disease activity at some stage of the survey. Thus, only fourteen patients were inactive throughout the survey and $23(11 \cdot 5$ per cent.) at all four follow-up assessments, compared with 100 patients (50 per cent.) who were active on every occasion. There was thus no evidence to show that the disease tended to pass from an active to an inactive stage, but rather that individual cases maintained their own levels of activity or fluctuated between fairly narrow limits.

On the whole the cases with the least signs of activity were the most favourably placed as regards functional capacity. Of the 23 who were consistently inactive at follow-up, fifteen were in Grade I, four in Grade II, and one in Grade III at the fourth assessment. Table XV shows the functional grades at the fourth assessment of cases which were inactive at some stage of the survey and of those who were active throughout. The difference is highly significant $\left(\chi^{2}=25 \cdot 6 ;\right.$ d.f. $\left.3 ; P<0 \cdot 001\right)$.

TABLE XV

RELATIONSHIP BETWEEN DISEASE ACTIVITY THROUGHOUT SURVEY AND FUNCTIONAL CAPACITY AT FOURTH ASSESSMENT

\begin{tabular}{|c|c|c|c|c|c|}
\hline \multirow{2}{*}{\multicolumn{2}{|c|}{ Disease Activity }} & \multicolumn{4}{|c|}{ Functional Grade } \\
\hline & & $\mathbf{I}$ & II & III & IV \\
\hline $\begin{array}{c}\text { Inactive on at } \\
\text { Least One Occasion }\end{array}$ & $\begin{array}{l}\text { No. } \\
\text { Per cent. }\end{array}$ & $\begin{array}{c}34 \\
27 \cdot 9\end{array}$ & $\begin{array}{c}56 \\
45 \cdot 9\end{array}$ & $\begin{array}{c}26 \\
21 \cdot 3\end{array}$ & $\begin{array}{l}9 \\
4 \cdot 9\end{array}$ \\
\hline Active Throughout & $\begin{array}{l}\text { No. } \\
\text { Per cent. }\end{array}$ & $\begin{array}{c}7 \\
9 \cdot 0\end{array}$ & $\begin{array}{c}26 \\
33 \cdot 3\end{array}$ & $\begin{array}{c}28 \\
35 \cdot 9\end{array}$ & $\begin{array}{c}17 \\
21 \cdot 8\end{array}$ \\
\hline
\end{tabular}

TABLE XIV

AGE AND FUNCTIONAL CAPACITY

\begin{tabular}{|c|c|c|c|c|c|c|c|c|c|c|c|c|}
\hline \multirow{3}{*}{$\begin{array}{c}\begin{array}{c}\text { Age at 3rd } \\
\text { Assessment (yrs) }\end{array} \\
0-49\end{array}$} & \multirow{2}{*}{\multicolumn{2}{|c|}{$\begin{array}{c}\text { Functional Grade at } 3 \text { rd } \\
\text { Assessment }\end{array}$}} & \multicolumn{8}{|c|}{ Functional Grade at 4th Assessment (per cent.) } & \multirow{2}{*}{\multicolumn{2}{|c|}{$\underset{\text { (per cent.) }}{\text { Deaths }}$}} \\
\hline & & & \multicolumn{2}{|l|}{ I } & \multicolumn{2}{|c|}{ II } & \multicolumn{2}{|c|}{ III } & \multicolumn{2}{|c|}{ IV } & & \\
\hline & $\begin{array}{l}\text { I and II } \\
\text { III and IV }\end{array}$ & $\begin{array}{l}(58) \\
(16)\end{array}$ & $\begin{array}{c}41 \cdot 4 \\
-\end{array}$ & (24) & $\begin{array}{l}48 \cdot 3 \\
12 \cdot 5\end{array}$ & $\begin{array}{r}(28) \\
(2)\end{array}$ & $\begin{array}{r}8 \cdot 6 \\
56 \cdot 2\end{array}$ & $\begin{array}{l}\text { (5) } \\
\text { (9) }\end{array}$ & $\overline{18 \cdot 8}$ & (3) & $\begin{array}{r}1 \cdot 7 \\
12 \cdot 5\end{array}$ & $\begin{array}{l}\text { (1) } \\
\text { (2) }\end{array}$ \\
\hline $50-59$ & $\begin{array}{l}\text { I and II } \\
\text { III and IV }\end{array}$ & $\begin{array}{l}(47) \\
(27)\end{array}$ & $19 \cdot 1$ & (9) & $\begin{array}{l}48 \cdot 9 \\
11 \cdot 1\end{array}$ & (23) & $\begin{array}{l}21 \cdot 3 \\
44 \cdot 4\end{array}$ & $\begin{array}{l}(10) \\
(12)\end{array}$ & $\begin{array}{r}2 \cdot 1 \\
14 \cdot 8\end{array}$ & (1) & $\begin{array}{r}8 \cdot 5 \\
29 \cdot 6\end{array}$ & $\begin{array}{l}\text { (4) } \\
(8)\end{array}$ \\
\hline Over 60 & $\begin{array}{l}\text { I and II } \\
\text { III and IV }\end{array}$ & $\begin{array}{l}(45) \\
(43)\end{array}$ & $\begin{array}{r}15 \cdot 6 \\
2 \cdot 3\end{array}$ & $\begin{array}{l}\text { (7) } \\
\text { (1) }\end{array}$ & $\begin{array}{r}48 \cdot 9 \\
9 \cdot 3\end{array}$ & $\begin{array}{r}(22) \\
(4)\end{array}$ & $\begin{array}{l}20.0 \\
20.9\end{array}$ & $\begin{array}{l}\text { (9) } \\
\text { (9) }\end{array}$ & $\overline{34 \cdot 9}$ & (15) & $\begin{array}{l}15 \cdot 6 \\
32 \cdot 6\end{array}$ & $\begin{array}{r}(7) \\
(14)\end{array}$ \\
\hline
\end{tabular}


Erythrocyte Sedimentation Rate.-Isolated E.S.R. readings provided no reliable guide to the subsequent course of the disease. Consecutive readings over a period do, however, bear some relationship to the eventual functional capacity. There are several possible ways of combining a number of readings and it seemed that the least objectionable was to group patients according to the highest level noted during the period of observation. Table XVI divides the patients into five categories according to the highest reading obtained on admission, on discharge, and at the first assessment, and relates them to the functional capacity at the fourth assessment. In general, the higher the E.S.R. the worse the functional result. There is one exception to this. Patients with a very high E.S.R. did relatively well. This agrees with the observation that patients with a severe, acute onset tended to react favourably.

\section{TABLE XVI}

RELATIONSHIP BETWEEN E.S.R. READINGS ON ADMISSION, DISCHARGE, AND FIRST ASSESSMENT AND FUNCTIONAL CAPACITY AT FOURTH ASSESSMENT

\begin{tabular}{c|c|c|c|c|c}
\hline \multirow{2}{*}{$\begin{array}{c}\text { Maximum E.S.R. } \\
\text { (of 3 readings) } \\
\text { (mm./hr) }\end{array}$} & $\begin{array}{c}\text { No. } \\
\text { of } \\
\text { Cases }\end{array}$ & \multicolumn{2}{|c|}{$\begin{array}{c}\text { Grade of Functional Capacity at } \\
\text { 4th Assessment (per cent.) }\end{array}$} \\
\cline { 3 - 6 } & I & II & III & IV \\
\hline Below 20 & 16 & $31 \cdot 3$ & $56 \cdot 3$ & $12 \cdot 5$ & - \\
$20-39$ & 51 & $21 \cdot 6$ & $54 \cdot 9$ & $19 \cdot 6$ & $3 \cdot 9$ \\
$40-59$ & 53 & $20 \cdot 8$ & $43 \cdot 4$ & $28 \cdot 3$ & $7 \cdot 5$ \\
60-79 & 46 & $10 \cdot 9$ & $32 \cdot 6$ & $32 \cdot 6$ & $23 \cdot 9$ \\
Over 80 & 33 & $27 \cdot 3$ & $21 \cdot 2$ & $36 \cdot 3$ & $15 \cdot 1$ \\
\hline
\end{tabular}

Sensitized Sheep Cell Test.-The results of the sensitized sheep cell test were related to functional capacity and disease activity. The test was performed twice, at the third and fourth assessments. Of the patients with two positive results, only 9 per cent. were in Grade I at the final assessment, compared with 39 per cent. of those with two negative results. 24 per cent. of patients with two positive results become inactive, in contrast to 44 per cent. of those with two negative results. There were 88 patients with two positive results and 66 with two negative results. The relationship between the results of the test and the level of functional capacity and disease activity was thus highly significant $(P<0.01)$. There was an equally significant relationship between functional capacity at the final assessment and the titres obtained in the test. When the titre was $1: 16$ or less, 40 per cent. of patients were in Grade I. At titres of 1:512 and over, only 14 per cent. of patients were in Grade I.
Presence of Nodules.-At the final assessment 27 patients were recorded as having nodules compared with 173 who were without. Five of those with nodules gave a negative sheep cell test, which is significantly fewer than the 81 out of 173 patients without nodules $\left(\chi^{2}=6.5\right.$; d.f. $\left.1 ; P<0 \cdot 02\right)$. Similarly, eleven of those with nodules were in functional Grades I or II ( 40.7 per cent.) compared with 110 $\left(64 \cdot 7\right.$ per cent.) of those without $\left(\chi^{2}=4 \cdot 7\right.$; d.f.1 ; $\mathrm{P}<0.05)$.

Effects of Treatment.-An attempt was made to compare the results on patients given treatment additional to the basic regimen during the follow-up period with patients who received no such treatment. Patients treated with steroids, phenylbutazone, parenteral iron, and gold showed no greater improvement than those who were not so treated. Moreover, the treated patients included an unusually large proportion who deteriorated. 'The reason for this was undoubtedly that patients were selected for treatment because they were showing some increase in disability. Quite clearly a follow-up survey of this type is unsuited to any kind of therapeutic trial.

Of some interest is the progress shown by patients readmitted to hospital for treatment during the follow-up period. Eleven cases improved, 32 were unchanged, and 36 deteriorated. The proportion deteriorating was more than twice that of the group as a whole, and this again illustrates the effect of selection. These results, also, contrast sharply with those obtained in the original period of hospital treatment.

\section{Social and Economic Factors}

Availability of Help.-The living standards of patients with rheumatoid arthritis depend very largely on the help available from relatives and friends. At the fourth assessment, therefore, a note was made of the patients living with their families, or within easy reach of them, and of those living alone The numbers living alone were: four of the 41 in Grade I (10 per cent.); fourteen of the 82 in Grade II (17 per cent.); and six of the 54 in Grade III (11 per cent.).

The 23 cases in Grade IV require special mention. Only thirteen were with their families. Four were living alone and six were in long-term hospitals. All the patients in this grade were confined to bed or to a chair so that it was particularly undesirable that any of them should live alone and, in those that did so, a noticeable deterioration in living conditions had occurred. 
Unresolved Social Problems.-In 44 cases there were social problems which were still unresolved at the fourth assessment. These problems were connected with resettlement, finance, domestic care, housing, and personal and family difficulties.

The frequency of unresolved problems was closely related to the individual's functional capacity. Only two patients in Grade I had any problems at all, one connected with resettlement and the other with domestic care. A slightly higher proportion, eight out of 82 (10 per cent.), was found in the Grade II patients. As might be expected, it was the Grade III patients, thirteen out of 54 (43 per cent.), and the Grade IV patients, thirteen out of 23 (57 per cent.), who provided the bulk of those needing assistance.

Domestic care was by far the most common cause of difficulty, accounting for 26 of the unresolved problems. Next came housing (eight), resettlement (five), and family and personal troubles (four); only one patient was still in need of financial advice.

Of the total number of social problems which had to be dealt with, domestic care (74) headed the list. Financial help was required by 43 patients, help with resettlement by 45 , housing by 37 , and advice on personal and family matters by 51 . The small number of residual problems gives some measure of the extent to which the medical social workers were able to improve the living standards of these patients.

Morale and Ability to Live with Disease.-It was thought that the patient's morale and ability to live with his disease might affect his adjustment to physical and social circumstances. Accordingly an estimate of morale was made at the fourth assessment based on appraisals made at regular intervals by the medical social worker. Patients were considered under the headings: Good, Fair and Poor. Those rated as Good had shown a recognizable desire to lead a normal life as far as their disability allowed. Those rated as Fair had shown a tendency to accept their disability to a moderate or fluctuating degree. Those rated as Poor seemed overwhelmed by their disease and were disinclined to co-operate with medical treatment.

Altogether 119 patients were rated as Good, 58 as Fair, and 23 as Poor. The distribution of cases was closely related to functional capacity. 76 per cent. of those with good morale were in Grades I and II compared with 45 per cent. of the fair, and 22 per cent. of the poor. A similar relationship was seen between morale and social circumstances. Of those rated as poor, only 30 per cent. had shown any social improvement since admission, compared with 68 per cent. of those rated as fair and 80 per cent. of those rated good. Both morale and social circumstances seem, however, to be largely dependent on functional capacity so that this last result is not altogether surprising.

Changes in Social Circumstances. - At each assessment the patient's social circumstances were evaluated as: improved, unchanged, or worse. Between admission and the fourth assessment 71.5 per cent. had improved, 7.0 per cent. were unchanged, and 21.5 per cent. had deteriorated. Between the third and fourth assessment 12 per cent. had improved, 35 per cent. had deteriorated, and the remainder were unchanged. Of the 24 patients whose social position had improved over this period, fourteen had done so for medical reasons and ten for social reasons. Of the seventy patients who had deteriorated, 36 had done so for medical reasons and 21 for social reasons, while in the rest the reasons could not be classified. The majority of patients whose social position had deteriorated through medical causes were in Grade III or IV at the fourth assessment. Otherwise there was no distinct relationship between functional grades and the distribution of medical and social causes for social change.

\section{Summary and Conclusions}

The results of this latest study confirm the main conclusions reached in previous communications (Duthie and others, 1955, 1957). Of the 200 survivors available for assessment at the latest survey, some 9 years after discharge from hospital, 20.5 per cent. were without significant residual disability, 41 per cent. were moderately incapacitated, 27 per cent. were more severely crippled, and 11.5 per cent. had become entirely dependent on others.

The death rate among the group over the years was higher than in the general population at all ages and in both sexes, but causes of death did not appear to differ from the expected pattern. Mortality was highest among those most severely affected by the disease. This must be borne in mind in reviewing the results, since the absence of the most severely affected may give rise to an over-optimistic view.

Between discharge from hospital and the first assessment some 2 years later the overall pattern was one of improvement. From then onwards there was a gradual but progressive deterioration in the functional status of the group as a whole, due in part at least to increasing age and degenerative changes in previously damaged joints. The disease remained moderately active in the majority of patients throughout the period of observation, but 
capacity for useful employment was reasonably well maintained among the survivors.

With regard to prognosis, it was confirmed that the outlook was best in those patients in whom the onset was acute and who were admitted to hospital within one year of onset. Age and sex did not appear to exert any direct influence. It was confirmed that the functional capacity of the individual patient on discharge from hospital provided a fairly reliable index of future progress.

Those patients in whom the disease was rated as inactive on at least one occasion during the survey fared distinctly better than those whose disease remained active throughout.

Although isolated readings of the E.S.R. were of little prognostic significance, consideration of the readings on admission and discharge and at the first assessment provided some guidance.

The results of the sensitized sheep cell test had a significant relationship to prognosis.

The presence of nodules tended to be associated with more severe forms of the disease.

Treatment in addition to the basic regimen appeared to convey no additional benefit.

A study of social and economic factors indicated a close relationship between domestic or financial difficulties and the degree of crippling, as might be expected, but the relatively small number of unresolved problems at the last assessment was a clear indication of the important part played by medical social workers in the long-term care of the disabled. Maintenance or loss of morale was also intimately related to the degree of disability.

The groups which showed the greatest initial improvement were those whose musculature was likely to be most efficient-the young rather than the old, men rather than women, manual rather than sedentary workers. This would suggest that benefit derived from treatment was due to the physical measures used and not so much to a reduction in disease activity.

The main argument for admission to hospital early in the course of the disease must be that such measures are most likely to be effective at this stage. The training of these patients while in hospital in the use of splints, home physiotherapy, and remedial exercises in conjunction with subsequent regular medical supervision, may largely account for their more favourable course. If these conclusions are valid, they certainly constitute a powerful argument in favour of hospital treatment early in the disease and for the provision of adequate medical and social supervision after discharge.
A preliminary report on this study was given at the Tenth International Congress on Rheumatic Diseases in Rome in 1961.

During the period when this work was carried out, the Rheumatic Diseases Unit was in receipt of grants from the Nuffield Foundation, the Medical Research Council, the Empire Rheumatism Council, and Boots Pure Drug Company Limited, and one of us (F.D.B.) was supported by a fellowship from the Canadian Arthritis and Rheumatism Society.

\section{REFERENCES}

Brown, P. E., and Duthie, J. J. R. (1958). Ann. rheum. Dis., $17,359$.

Bywaters, E. G. L., and Dresner, E. (1952). Quart. J. Med., 21, 463.

Cobb, S., Anderson, F., and Bauer, W. (1953). New Engl. J. Med., 249, 553.

Duthie, J. J. R., Brown, P. E., Knox, J. D. E., and Thompson, M. (1957). Ann. rheum. Dis., 16, 411. Thompson, M., Weir, M. M., and Fletcher, W. B. (1955). Ibid., 14, 133.

Kellgren, J. H., Lawrence, J. S., and Aitken-Swan, J. (1953). Ibid., 12, 5.

Scottish Life Tables, 1950-52 (1954). Edinburgh, H.M.S.O.

Short, C. L., and Bauer, W. (1948). New Engl. J. Med., 238, 142.

\section{Evolution et pronostic de l'arthrite} rhumatismale. Nouveau rapport

\section{RÉSUMÉ}

Les résultats de cette dernière étude confirment les conclusions principales des travaux précédents (Duthie et coll., 1955, 1957). Sur 200 survivants disponibles pour l'évaluation à la dernière enquête, 9 ans environ après leur sortie de l'hôpital, 20,5 pour cent ne présentaient pas d'incapacité résiduelle appréciable, 41 pour cent étaient modérément infirmes, 27 pour cent étaient plus sévérément estropiés et 11,5 pour cent étaient entièrement à charge des autres.

La mortalité dans ce groupe au cours de ces années était supérieure à celle dans la population générale d'un âge et de sexe correspondants, mais il y avait peu de différence en ce qui concerne les causes des décès. Il faut bien en tenir compte lorsqu'on considère les résultats, étant donné que l'absence des plus affectés peut mener à des conclusions trop optimistes.

Entre la sortie de l'hôpital et la première évaluation deux ans après, le tableau général était celui d'amélioration. Après cela on observe une détérioration graduelle mais inexorable de l'état fonctionnel du groupe entier, due tout au moins en partie, à l'âge avançant des malades et à des lésions de dégénérescence dans des articulations déjà altérées. La maladie demeurait modérément active 
chez la majorité des malades pendant toute la période d'observation, mais la capacité pour suivre un emploi utile se maintenait assez bien parmi les survivants.

En ce qui concerne le pronostic, on a confirmé qu'il était le meilleur pour les malades chez qui le début avait été aigu et que l'on avait admis à l'hôpital au cours de la première année de leur maladie. L'âge et le sexe n'y semblaient jouer aucun rôle direct. On a confirmé que la capacité fonctionnelle du malade individuel à sa sortie de l'hôpital offrait un assez bon critère pour juger son future progrès.

Le patient dont la maladie fut considérée inactive même une fois au cours de l'enquête allait décidément mieux que ceux dont la maladie demeurait active tout le temps.

Bien que des determinations isolées de la vitesse de sédimentation globulaire aient peu d'importance pronostique, leur considération à l'entrée, avant la sortie et à la première évaluation du malade offre quelques indications sur son future.

La réaction de Waaler-Rose est un indice pronostique significatif.

Les nodosités d'Heberden tendent à s'associer à des formes plus graves de la maladie.

Un traitement supplémentaire au régime essentiel ne semblait pas octroyer de bénéfice additionnel.

Comme on l'avait prevu, l'étude des facteurs sociaux et économiques révéla un rapport étroit entre les difficultés pécuniaires et de ménage d'une part et le degré d'incapacité de l'autre. A la dernière évaluation le nombre relativement petit de problèmes irrésolus indiqua clairement l'importance des travailleurs médico-sociaux dans les soins à long terme des invalides. La conservation ou la perte du moral se trouvait également associée au degré d'incapacité.

Les groupes qui accusaient la plus grande amélioration initiale étaient celles dont la musculature était censée être la plus efficace-les jeunes plutôt que les vieux, les hommes plutôt que les femmes et les travailleurs manuels plutôt que les sédentaires. Cela semble indiquer que le bénéfice du traitement était dû plus à la physiothérapie qu'à la réduction de l'activité de la maladie.

La raison principale pour l'hospitalization à la période de début de la maladie doit être le fait que le traitement physique peut être le plus efficace à cette période. L'education de ces malades pendant leur séjour à l'hôpital dans l'emploi des attelles, la physiothérapie domiciliaire et l'exercice curatif ainsi que la consécutive surveillance médicale régulière peuvent expliquer en grande partie leur progrès plus favorable. $\mathrm{Si}$ ces conclusions sont valides, elles présentent indubitablement un argument puissant en faveur du traitement hospitalier précoce de cette maladie et en faveur de dispositions pour assurer une surveillance médicale et sociale suffisante après le renvoi de l'hôpital.

\section{Evolución y pronóstico de la artritis reumatoide. Nuevo informe}

\section{SUMARIO}

Los resultados de esta última investigación confirman las conclusiones principales de los trabajos anteriores
(Duthie y col., 1955, 1957). De 200 sobrevivientes disponibles esta vez, cerca de nueve años después de su salida del hospital, un 20,5 por ciento manifestaron poca incapacidad residual, en un 41 por ciento la incapacidad fué moderada, en un 27 por ciento bastante grave y en un 11,5 por ciento la dependencia de otros fué completa.

A pasar los años, la mortalidad en este grupo fué superior a la en la población general de edad y sexo correspondientes, pero hubo poca diferencia respecto a las causas de muerte. Al considerar los resultados hay que tomar esto en cuenta, ya que la ausencia de los más afectados pudiera llevar a conclusiones demasiado optimistas.

Entre la salida del hospital y la primera valoración dos años más tarde, el cuadro general fué uno de mejoría. Después se observó un deterioro gradual pero inexorable del estado funcional del grupo entero, debido a lo menos en parte, al envejecimiento y a lesiones degenerativas en articulaciones ya afectadas. La enfermedad quedó moderadamente activa en la mayoría de los enfermos durante todo el período de observación, pero la capacidad de seguir una ocupación útil se mantuvo bastante bien en los sobrevivientes.

Respecto al pronóstico, se confirma que éste fué mejor para los enfermos con un comienzo agudo, hospitalizados dentro de un año del comienzo. La edad y el sexo no parecían desempeñar un papel directo. Se confirma también que la capacidad funcional del enfermo individual a su salida del hospital constituía un indicio bastante correcto para juzgar su progreso futuro.

El paciente cuya enfermedad fué considerada inactiva una vez siquiera en el curso de la investigación, lo pasaba decisivamente mejor que los cuya enfermedad fué activa sin interrupción.

Aunque determinaciones aisladas de la velocidad de sedimentación eritrocitaria tuviesen poca importancia pronóstica, su consideración al tiempo de entrar al hospital, al de salir y al de la primera valoración ofrece ciertas indicaciones respecto al futuro del paciente.

La reacción de Waaler-Rose es un indicio pronóstico significativo.

Los nódulos de Heberden tienden a asociarse con formas más graves de la enfermedad.

Un tratamiento suplementario al régimen fundamental no parece proporcionar beneficio adicional.

El estudio de los factores sociales y económicos reveló la anticipada relación estrecha entre las dificultades monetarias y domésticas por una parte y el grado de incapacidad por la otra. Sin embargo en la última valoración el número de problemas sin resolver fué relativamente pequeño, lo que indica claramente la importancia de los trabajadores médico-sociales en el cuidado a plazo largo de los incapacitados. El mantenimiento o la pérdida de la moral se vieron también asociados al grado de incapacidad.

Los grupos con mayor mejoría inicial fueron aquellos en que la musculatura se consideraba más eficazjóvenes más bien que viejos, hombres más bien que mujeres, y trabajadores manuales más bien que sedentarios. Eso parece indicar que el beneficio del tratamiento se debió más a la fisioterapia y menos a la reducción de la actividad morbosa.

El argumento principal en favor de hospitalización 
temprana debe ser el hecho de que la fisioterapia y medidas de rehabilitación tienden a ser más eficaces al principio de la enfermedad. La educación de estos enfermos en el hospital en el uso de tabillas, fisioterapia domiciliaria, exercicios terapéuticos junto con vigilancia médica

regular pueden explicar en gran parte su progreso más favorable. Si estas conclusiones son válidas, entonces presetan indudablemente un argumento poderoso en favor de medidas para asegurar una vigilancia médica y social suficiente después de la alta del hospital. 